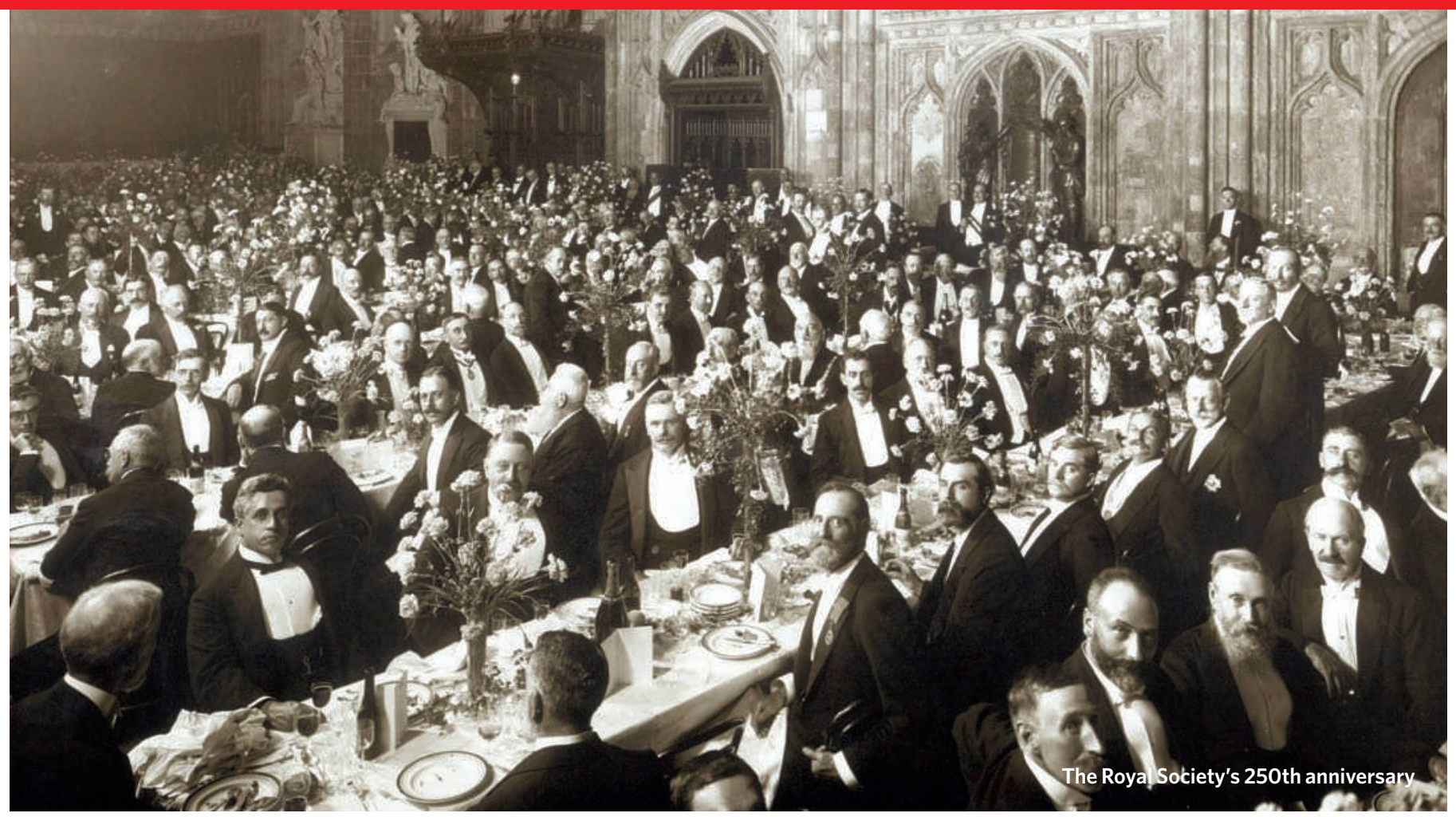

In the best company

The grandfather of scientific national academies is staging major celebrations this week for its 350th birthday. But, like similar elite groups around the world, Britain's Royal Society has had to work hard to stay relevant and influential, reports Colin Macilwain.

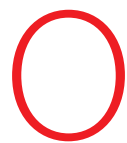

ne thing that scientists have learned since the seventeenth century is how to throw a party. This week, the Queen is set to celebrate with hundreds of Britain's most brilliant minds, kicking off a summer of festivities to mark the 350th anniversary of the Royal Society of London for the Improvement of Natural Knowledge.

The public will be invited to partake in a carnival of celebrity lectures, debates, live TV shows and exhibits to showcase science and the Royal Society's role in it. The choice of the South Bank - London's main arts centre and a major tourist bazaar - for the tenday extravaganza signals the society's hunger to be seen as up to date, inclusive and important, not exclusive and aloof.

National academies of science in more than 100 nations are aiming for the same goal, with varying success. Many were born in an era when a few select individuals practiced science, and those groups evolved to offer behind-the-scenes advice to governments. Now, the academies represent much more diverse communities, and they must take their messages not only to governments but also directly to the public.

The Royal Society and its kindred academies have had to evolve in their own unique ways to meet the challenges of the twenty-first century.
They try to offer sober advice on some of the most divisive issues - such as climate change, reproductive biology and genetically modified food - without offending their patrons or members. They must be seen to be independent of government, despite considerable reliance on public funding. And they need to reflect the growing ethnic and gender diversity of the scientific community, while still selecting members on the basis of their scientific reputations.

Ever more nations are establishing academies of their own. They range from the Ethiopian Academy of Sciences in Addis Ababa, which opened for business two months ago, to the US National Academy of Sciences (NAS) in Washington DC, which employs 1,100 full-time staff members to turn out 200 reports each year for the government.

"The academy's function is to provide the consensus view of the scientific community," says Bruce Alberts, former president of the NAS. Given the range of topics that it handles and the diversity of views within that community, he says, "it is very difficult to do".

The Royal Society and the NAS are two of the largest independent scientific academies in the world, and illustrate two principal models of operation. The Royal Society is a self-constituted club with no formal, official role in government; the NAS is chartered to provide advice at the behest of the US Congress. (A different type of academy, of which the Chinese Academy of Sciences is an example, is effectively part of the state and runs many of the government science programmes in several communist and formerly communist countries.)

Some of the differences between the Royal Society and NAS models can be traced back to their respective histories. The NAS, like many other national academies, was set up by a patron - President Abraham Lincoln, at the height of the American Civil War, in 1863. The Royal Society, in contrast, was started by scientists themselves, expressly to promote science. But these founders were strong supporters of a monarchy recently restored after the English revolution - and their society soon sought, and got, the patronage of King Charles II.

Early on, the Royal Society made clear that it owed allegiance not to king and country but to scientific truth. The society maddened King George III, for example, by siding with its fellow Benjamin Franklin in a debate about the shape of lightning conductors, even as Franklin fomented rebellion in the colonies.

The society has continued to chart its own course. Like other national academies, it establishes its rules and elects its own members - an arrangement that draws charges of elitism.

"There's a sense of pride here in being elitist: 
the proportion of scientists who are fellows is very small," says Martin Rees, who became the society's president in 2005. "But we're elite only in the sense that we ought to be elite."

\section{High standards}

The society maintains its standards through a complex annual election process, which has evolved since it first started elections to select members in 1847. Recommendations for new fellows go to a network of sectional committees, which examine the nominations. They pick the top candidates and put them before the full society to endorse, rather than having a general election of all the nominations.

The committees have tried to pull down the average age at which fellows are elected. "There's more likelihood now of electing fellows in mid-career, in their mid-40s rather than their late 50s," says John Krebs, a zoologist at the University of Oxford, UK, and chairman of the Royal Society's science policy advisory group, who was only 39 when elected in 1984.

Members are also asked to submit letters nominating individuals for positions in office. Some 200 of them did so before April's announcement that Paul Nurse, a cell biologist and president of Rockefeller University in New York, would succeed Rees at the end of this year.

The empire that Nurse will inherit has two principal arms. Most of the Royal Society's work, paid for by a $£ 52$-million (US\$77-million) block grant from the government, supports early-career researchers through various types of awards, as well as 305 highly prestigious university research fellowships. The society's endowment financed $£ 13$ million of policy work and other activities this year, generating statements and reports that provide the Royal Society's public face.

Peter Hennessy, a historian at Queen Mary, University of London and a leading authority on British governance, says that the Royal Society's stock in the corridors of power is high. "It has always had an influence in Whitehall, where it is seen as a gold-standard institution," he says. "When the Royal Society has an input, people listen to it."

William Waldegrave, science minister in the Conservative UK government from 1992 to 1994, agrees. He relied on it, in particular, to help him pick scientific advisers. "I think the Royal Society does have very high prestige; it is one of these brands that always carries weight," he says. $\mathrm{He}$ is dismissive of the idea that the block grant could enable the government to influence the society. "It would be a very rash minister who would try to pull that lever," he says.
Since Waldegrave's time in office, the Royal Society has assumed a more aggressive and professional approach to public affairs. The change was driven partly by high-profile scientific crises a decade ago, concerning genetically modified food and bovine spongiform encephalopathy (BSE). These shook public confidence in science, and, to an extent, science's confidence in itself.

The Royal Society responded in 2000 by electing Robert May, an Australian physicistturned-ecologist, as its 58th president. May had previously served as the UK government's chief scientific adviser, and he helped transform the Royal Society from an inward-looking body into a public force, says Krebs. With his government experience, May "could see how an independent voice like the Royal Society's could get real traction", Krebs says.

Although less voluble than May, Rees is a media-savvy scientist who has helped to keep the society in the public eye. Under his presidency, the society set up a Science Policy Centre, advised by Krebs' group, to consider policy issues and decide which the Royal Society should report on.

One of the centre's first publications was a report on geoengineering, released in September 2009. James Wilsdon, the centre's director, says that the report has "helped to change the terms of the debate", prompting British research councils to officially consider some geoengineering approaches, such as cloud seeding, for the first time, as well as triggering their serious discussion in the media.

Rees has used the society's anniversary celebrations to encourage a large number of TV documentaries on the BBC and other channels, most of them celebrating the achievements of Royal Society fellows past and present. (As part of the festivities next week, the Royal Society and Nature will co-host a conference that looks ahead 50 years on topics such as data storage and scientific careers.) Rees has also raised about $£ 100$ million from individuals and businesses for the society's own endowment, almost doubling its size.

Rees's reign is not without its detractors. Some say that the Royal Society has retreated from politically contentious issues, to place greater emphasis on advocating science funding.

In April, Richard Pike, chief executive of the Royal Society of Chemistry in London, Britain's largest learned society, criticized a government plan to confer with the Royal Society on budget matters, questioning its independence from government. "They seem not to be challenging government policy as forthrightly as they could be," says Pike. Rees says that Pike is the only individual to make this criticism, and that others accept that the Royal Society's policy arm is independent of government.

\section{Speaking out on policy}

Across the Atlantic, the NAS has even closer ties with its government, and so has evolved in different ways from the Royal Society. Most of the academy's studies are requested by Congress and are paid for through contracts with federal agencies. These contracts enable the academy and its sister organizations in Washington DC, the National Academy of Engineering and the Institute of Medicine, to support a large staff of specialists.

The quasi-governmental status of the academy places its operations under more scrutiny than those of the Royal Society. A decade ago, for example, environmental groups went to court to argue that the academy should not be allowed to bar the public from panel discussions. "At the time it was a very serious threat," says William Colglazier, the academy's executive officer. The NAS adopted reforms, such as public consultation on panel membership and some open meetings, that have strengthened the academy's processes, he says.

The academy has also come under fire for the lack of diversity in its membership. Its president, atmospheric scientist Ralph Cicerone,

\section{TWO ELITES \\ The Royal Society of London and the US National Academy of Sciences are two of the biggest and most well-established national academies. \\ Royal Society \\ Fellows: \\ Foreign members: \\ Budget for 2008/09: \\ Staff size: \\ Number of 2010 inductees: \\ Percentage of women among 2010 inductees: \\ Living Nobel Prize winners: \\ National Academy of Sciences \\ Members: \\ Foreign associates: Budget for 2009: $\quad £ 176$ million* \\ Staff size: 1,100 * \\ Number of 2010 inductees: $\quad 72$ \\ Percentage of women among 2010 inductees: \\ Living Nobel Prize winners: \\ 21 140 (plus 60 foreign)}




\section{660}

Christopher Wren, Robert Boyle and ten other men gather at Gresham College for a drink and decide to found "a Colledge for the Promoting of Physico-Mathematical Experimentall Learning.
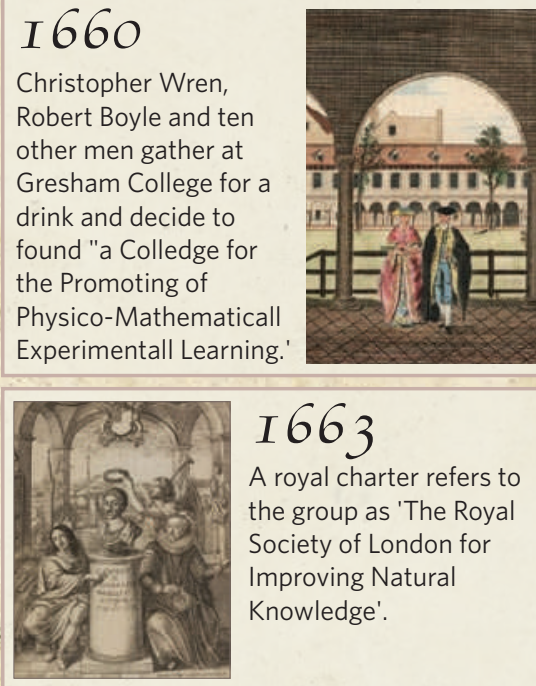

\section{3}

A royal charter refers to the group as 'The Royal Society of London for Improving Natural Knowledge'.

\section{2}

Benjamin Franklin performs his famous kite experiment for the Royal Society. Two decades later, the society is torn by a debate about the best shape for lightning conductors.

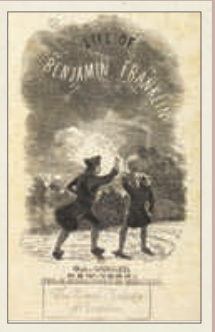

\section{847}

The decision is made to elect a limited number of new fellows each year, on the basis of their scientific reputation, effectively blocking entry for wealthy amateurs.

\section{850}

The society receives its first $\notin 1,000$ grant from the British government for private scientific research.

\section{0}

The society declines to represent the British humanities at an international conference, opening the way for the establishment of a separate British Academy, representing learning outside of the hard sciences.

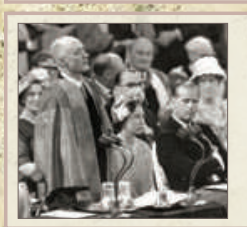

\section{0}

Queen Elizabeth II helps to celebrate the Royal Society's 300th anniversary.

\section{$20 I O$}

The Royal Society stages a summer of festivities for its 350th anniversary.

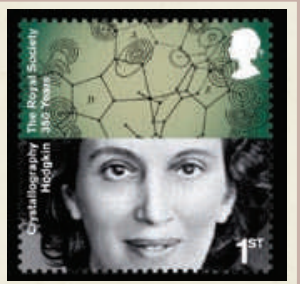

concedes that the number of female members - about $12 \%$ - is "not good enough", and is also concerned about its under-representation of Asian-Americans, the causes of which, he says, the academy is now looking into.

The academy is cautious about taking a stand on policy issues, although it has, for example, issued statements on the teaching of evolution and creationism, most recently in 2008. The NAS has also joined with other academies around the world in several consensus statements on what is known about global warming. "We make policy statements of our own pretty rarely," says Cicerone. "We have to choose topics where what we say is going to matter."

May, who is also a member of the NAS, observes that the US academy is "more constrained" than the Royal Society "by the fact that it has 1,100 staff producing reports, and depending on government money", so that it "has to think twice" about issuing critical reports that might make enemies in Congress.

Colglazier says that the NAS has honed its procedures over the past century to ensure the independence of its reports. "The academy is perceived as a place to go for impartial study," he says, "and that reputation could be lost very easily."

Some would like the academy to speak out more. Robert Park, a physicist at the University of Maryland in College Park who comments on science policy issues in his online newsletter What's New, says that he'd like to see the academy take a more strident line on hot issues such as creationism. "They would be better off in the long run if they ignored Congress and said the things that need to be said, without any hesitation," he says.

Others contend that the US academy is wiser to hold its fire and maintain its influence. That remains strong, particularly among the 'barons' who run congressional committees, says David Goldston, former chief of staff on the House science committee. "They are among the only honest brokers in an increasingly polarized political environment," he says.

In 2001, for example, the academy issued a report on climate change that helped to constrain the Bush administration, and its allies in Congress, from openly questioning the evidence linking human activity to global warming. And last month, the academy published a trio of massive reports called 'America's Climate Choices', which explains the science of climate change and makes the case for reducing emissions and for adapting to anticipated conditions. Although many of its conclusions could be found in the 2007 assessments issued by the Intergovernmental Panel on Climate Change (IPCC) in Geneva, Switzerland, the academy reports could influence US lawmakers as they debate climate legislation this summer.

\section{Global movement}

Around the globe, national academies are seeking to expand their public role to achieve the kind of influence enjoyed by the Royal Society and the NAS. "There's a whole move now to make academies a voice for science in every nation of the world," says Bruce Alberts.

In Europe, only a few countries have established national academies as influential in their own capitals as the Royal Society. Two of the strongest are the Royal Swedish Academy of Sciences in Stockholm, founded by Carl Linnaeus and other scientists in 1739, and the Royal Netherlands Academy of Arts and Sciences in Amsterdam, founded in 1808.

Germany took a major step in 2007, when the federal government officially recognized the Leopoldina, in Halle, as the country's scientific academy for the first time. Jörg Hacker, the biologist who assumed its presidency in March, says that it is increasing its staff to about 70 , and that it will be fully independent, despite its reliance on federal and state government funds.

In Africa, numerous academies have been established or reconstituted, including the Ethiopian Academy of Sciences. The track record of African academies has been mixed so far, with several struggling to attract young scientists and effective leaders. But Alberts credits the Academy of Science of South Africa with helping to finally reverse the government's denial that HIV causes AIDS.

Increasingly, national academies have sought to unite on global issues such as climate change. The InterAcademy Panel based in Trieste, Italy, was created in 1993 and has issued numerous joint policy statements on behalf of its 104 member academies. An InterAcademy Council, meanwhile, was set up in 2000 with a secretariat in Amsterdam, to undertake major studies. Its current review of the IPCC for the United Nations is due in late August.

Critics may contend that the public is indifferent to the academies' grand pronouncements, and that their reports are valued by politicians more for the cover they provide than for the carefully nuanced information they contain.

But supporters remain assured that a wider purpose is being served. "We only address scientific issues," says Stephen Cox, executive secretary of the Royal Society, "and we have become more important because there are so many more issues today that have a scientific component."

Colin Macilwain is a freelance writer based in Edinburgh, UK.

See Editorial, page 986, and Opinion, page 1009. 